\author{
DOI: $10.26693 / j m b s 06.01 .345$
}

UDC 796.814:796.012.2-048.58-057.874

Baraliuc I., Manolachi V., Polevaia-Secareanu A., Cotorcea A.

\title{
Particularities of Initial Selection of Primary School Age Sambo Wrestlers Based on the Study of Psychomotor Abilities
}

\author{
State University of Physical Education and Sport, \\ Chisinau, Moldova
}

poleangela1975@mail.ru

The purpose of the study was to identify the particularities of psychomotor abilities in 8-9 years old sambo athletes in the process of initial sport selection.

Material and methods. The research presents an algorithm of the leading factors of the step-by-step selection of 165 8-9-year-old pupils for sambo wrestling. The first stage of selection was a thorough checkup, which determined that more than $50 \%$ of the total number of pupils had disturbance of morphology and functionality of different body systems, there remained 68 examinees. At the third stage of selection the identification of intellectual abilities showed that only $73.53 \%$ of pupils out of 68 (i.e. 50 pupils) had an average level of attention stability. According to the appreciation of psychomotor abilities of pupils we identified a decrease on the examinees number with $20 \%$ out of 50 pupils. At the special stage of selection $17.5 \%$ of $8-9$ years old pupils, in $70 \%$ of cases (i.e. for the majority of tests) failed to execute the requirements for motor abilities and coordination capacity.

The basic experiment was elaborated and realized on the basis of an yearlong pedagogical experiment for which we organized two experimental study groups of sambo wrestlers in their first year of sport training: control group, that included 15 pupils that did not undergo any special selection, and the experimental group, consisting of 15 8-9 years old pupils that were specially selected. We created identical conditions for the learning and training process throughout a year for both groups. However, only in the experimental group we included the experimental methodology of sport diagnostics that contained a complex of scientifically based criteria and conditions.

Results and discussion. During the experiment we identified the indices of "timely" reaction of the sambo wrestlers in the control group which improved only by $6 \%$, compared to the experimental group (57\% more compared to the indices at the beginning of the experiment). It presented the dynamics of the tapping test of the sambo wrestlers in the control and experimental groups, from the first to the fourth period. The dynamics showed the local tiredness of the nervous and muscular system of the body, caused by the depression of their brain motor centers, which increased in both groups, but had a visible tendency of aggravation to the fourth period in the control group (from the first to the fourth period - within the limits of $62.80 \%$ ) compared to the experimental group, where the speed of elementary movements of children in the tapping test decreased inconclusively in every time period. Thus, at the end of the second period the results of the experimental group decreased by $11.25 \%$, to the end of the third period they lowered by $36.62 \%$, to the end of the fourth period they decreased by $15.55 \%$ of the data of the previous period, which in conclusion comprised the decrease from the first to the fourth period up to $63.42 \%$.

Conclusion. Thus, the veridically relevant situation of psychomotor development in the experimental group of sambo wrestlers, in our opinion, became possible due to their preliminary readiness (selection results) and the active experimental training action on them.

Keywords: selection, sambo, initial stage, sensorimotor.

Introduction. The modern approach to the process of sport selection is determined by the knowledge of a complex of the most important development particularities of the child functional body systems. This fact allows increasing the likelihood ratio of identification of more sport talented children at the stage of initial selection [1, 2, 3, 4, 5].

The particularity of the primary school age or second childhood period is characterized by the fact that the child's organs and systems continue to develop and improve, and in most cases, they reach the corresponding level of functional development $[6,7]$. In the 
development of children, the external world and the interrelation with it, are characterized by increasing difficulty and diversity. The given age is characterized by gradual increase of physiological lability of nerve centers and nerve process mobility at movement manifestation. Different speed indices have a moderate development: the time of motor reaction decreases, the speed of a single movement and the maximal movement tempo increase $[8,9]$.

In this regard a timely informing of trainers on athletes, new ideas and directions of the training process is of primary significance [10]. This necessity is increased also by the fact that in any field, every 5-10 years there is practically a complete revision of the accumulated scientific information. In these circumstances the trainers must possess intellectual abilities such as curiosity, discretion, perception of novelty and special rational creativity for being able to keep up with the rapid knowledge flux [11].

Moreover, the quick reformatting of political and social life conditions for the majority of European countries, as well as the whole world, exerts a significant impact on the sport formation as a special modern social activity of their citizens. In this context, the key factor of restructuring is the commercialization of sport, sport relations and even the selling of top athletes as goods $[12,13]$. This situation leads to the fact that the goal-oriented and systemic training and preparation activity of the specialists in education of highly qualified athletes, in some cases becomes unprofitable, outdated and most often with no chance to success.

It is only natural that for the achievement of high sport results it is necessary to have a significant intensification of training lessons and physical exercise, which requires a science-based search of talented young people that have motivation for motor development and functionally have access to significant muscle loading and high tempo of sport improvement and sport achievement [14].

The majority of authors when organizing the motor researches of the children that aspire to be selected for sambo, not always pay the due attention to the study of their psychomotor processes state, which is interrelated with the formation of motor abilities, and this fact provides the necessary development of body systems and vice versa, the improvement of motor abilities presupposes also the development of psychomotor abilities in an unified system $[5,6,7,15$ $16,17]$.

That is why in our case we consider that when observing the motor manifestations of boys during selection it is necessary to know their psychomotor state, which will exclude the abstract perception of their motor abilities and will offer an overall picture of their physical condition, including also the specific applicative and coordination condition.

In this context the scientific elaboration of a system of sport selection for sambo of 8-9 years old children that are almost formed from functional perspective and are already able to have deliberate motor actions, has an actual significance.

The purpose of the study was to identify the particularities of psychomotor abilities in 8-9 years old sambo athletes in the process of initial sport selection.

Material and methods. For the achievement of the research objectives the following methods were used: analysis of scientific and methodological literature and internet resources; pedagogical experiment, testing methods, mathematical statistical methods.

The study of scientific literature $[5,6,7,15,17$, $18,19]$ along with the opinion of trainers on the initial sport selection of 8-9 years old children for sambo wrestling allowed us to select out of a vast variety of the recommended, attractive and important factors only those that could present in a complex and heterogeneous way the most important aspects of the child body state, that are important for their future intensive sport improvement. An important condition for the formation of selection factor and methods, in our opinion, is their relative simplicity, age related accessibility and non-attachment to conditions. Moreover, all the tests must bring positive emotions to children who must be willing to do them.

This difficult dialectic task was solved by the elaboration on an algorithm of the main factors for the selection of 165 8-9 years old pupils for sambo wrestling.

Further on all the examinees were organized for the step-by-step selection passing following the proposed algorithm.

This way, the first selection stage was a thorough medical checkup, which determined that out of the total number of participants only 80 pupils remained. More than $50 \%$ of the total number of pupils have disturbance of morphology and functionality of different body systems. Thus, about $20 \%$ of pupils were obese, $10 \%$ had flatfoot, $12 \%$ had scoliosis, and $8 \%$ had visual function difficulty. Furthermore, the medical specialist identified that the children who successfully passed the medical checkup still had insufficient muscular development.

The second stage of selection of 8-9 years old pupils for sambo wrestling was the identification of their morphological status:

- Body mass index identification according to Kettle method;

- Identification of hereditary characteristics according to weight and height correlation between children and their parents. Thus, after analyzing the hereditary morphological characteristics there remained 68 pupils due to excessive weight and height correla- 
tion between children and their parents for those that did not pass this stage.

The next stage of their selection was the identification of the intellectual abilities of the studied 8-9 years old pupils according to the cognitive factor of "attention stability", that is necessary for a successful sport improvement in sambo wrestling. The testing of pupils with the use of Burdon-Anfimov alphabetic method had shown that only $73.5 \%$ pupils out of 68 (i.e. 50 pupils) had an average level of attention stability. 18 pupils ( $26.47 \%$ ) had a level of attention stability that was below average, which was unacceptable for selection.

The system of motor activity for wrestling, especially for sambo wrestling includes the emotional background of wrestle that characterize the specific abilities based on psychomotor system [13, 16, 19].

That is why the identification of the psychomotor abilities in 8-9 years old pupils at the initial stage of sport selection is extremely important because the age-related state of the nervous and muscular body system of the examinees also predetermines success in sport improvement for sambo wrestling, a timely motor reaction also predetermines the result of the wrestling meet [17].

At the fourth selection stage according to the appreciation of the psychomotor abilities we determined that only 40 pupils matched the necessary criteria, in other words the number decreased to $20 \%$ out of 50 pupils. Moreover, all 40 pupils passed the tapping test, 10 of them presented a timely response, 16 of them showed an admissible response delay, and 14 of them showed an admissible response acceleration.

A special selection stage of 8-9 years old pupils was the execution of the requests for motor abilities and coordination possibilities. It is special because 7 pupils $(17.5 \%$ ), in $70 \%$ (in other words, the majority of tests) failed to execute the corresponding motor representation, and those that met the selection criteria (33 pupils) barely managed to pass the test. The result was indicative of their motor under preparedness, and this fact would require in future additional effort for its elimination.

Proceeding from the scientific theoretical data, as well as personal trainer experience, we confirm that the psychomotor abilities of the studied children are an important factor of their functional and motor manifestation and require a study in different situational circumstances, including the period of their sambo training.

Our yearlong pedagogical experiment with experimental groups of beginner level sambo athletes involved the study of the complex state of their psychomotor abilities at the beginning and to the end of the training and study year, with a subsequent comparative analysis.
During the testing of the psychomotoric state of the sambo athletes the obtained data offered an insight into the development of the functional state of their central and peripheral nervous system (direct and inverse connections) with the help of the physical "motor" actions.

The functional stability of the neuromuscular system of the tested pupils allowed offering the "tapping test" which determined both the general maximally possible frequency of the setting wrist movement and for each out of 4,10 seconds period.

Research results. The obtained research data are presented in Table 1, where alongside with the comparative analysis we showed the contrastive process of the studied indices. In addition, the test results with the numbers 1, 2 and 3 underwent a comparative statistical analysis, and number $4(4.1 ; 4.2 ; 4.3)$ - contrastive.

As reflected by Table 1, almost all obtained results changed to increase by all tests. At the same time, these changes in results of beginner sambo athletes in both experimental groups for the yearlong research period are not univocal in their expression. This way the test results that underwent a comparative statistical analysis $(1 ; 2 ; 3$, Table 1$)$ are indicative of the fact that all of them at the initial stage for both studied groups (letters $\mathbf{K}$ and $\mathbf{O}$ ) have a relatively identical (unreliable) comparative level (with $P>0,05$ ). At the same time, the dynamics of these initial indices in the studied sambo athletes to the end of the research was positive for every studied test. In addition, the control group of sambo athletes for all tests $(1 ; 2 ; 3$ - Table 1) had better results to the end of the experiment, but it was statistically unreliable regarding the initial data (with $P>0.05$ ). We consider that this fact could be explained by the insufficient motor activity of sambo athletes in the control group in the training and study process, which also does not allow for the development of their "motor" and reactive abilities in difficult motor manifestations, specific for sambo wrestling.

At the same time, in the experimental group (letter $\mathbf{O}$ - Table 1 ), the initial results obtained at the beginning of the experiment for the studied tests (1; 2 ; 3) had a significant and veridic improvement compared to the final data with $P<0.001$. Moreover, the experimental group of sambo athletes, after ending the pedagogical experiment, had final indices for every test that reliably exceed the same indices of the control group, with $P<$ from 0.05 to 0.01 . This kind of reliably valid situation of psychomotor development in the experimental group of sambo athletes, in our opinion, was possible due to their active motor and training development with the help of the effective means and methods used by us. 
Table 1 - Presentation of the testing results and psychomotor ability development in sambo athletes of beginner level during the pedagogical experiment $\left(n_{k}-15 ; n_{0}-15\right)$.

\begin{tabular}{|c|c|c|c|c|c|c|c|}
\hline $\mathrm{nr}$ & Type of testing & $\begin{array}{l}\text { Groups } \\
\text { and } \\
\text { statistics }\end{array}$ & $\begin{array}{l}\text { Initial indices } \\
\qquad \bar{X} \pm m\end{array}$ & $\begin{array}{l}\text { Final indices } \\
\qquad \bar{X} \pm m\end{array}$ & $\mathrm{t}$ & $\mathrm{P}$ & $\begin{array}{l}\text { Expected } \\
\text { results }\end{array}$ \\
\hline \multirow{4}{*}{1.} & \multirow{4}{*}{$\begin{array}{l}\text { Tapping - test } \\
\text { (in } 40 \text { sec.): } \\
\text { nr. of touches }\end{array}$} & K & $188.00 \pm 7.30$ & $198.36 \pm 7.28$ & 1.50 & $>0.05$ & \multirow{2}{*}{230 and $>$} \\
\hline & & 0 & $200.00 \pm 73.3$ & $234.00 \pm 7.20$ & 4.95 & $<0.001$ & \\
\hline & & $\mathbf{t}$ & 1.64 & 3.44 & - & - & - \\
\hline & & $\mathbf{P}$ & $>0.05$ & $<0.01$ & - & - & - \\
\hline \multirow{4}{*}{2.} & \multirow{4}{*}{$\begin{array}{l}\text { Sensorimotor reaction } \\
\text { to sound }(\mathrm{sec})\end{array}$} & $\mathbf{K}$ & $0.470 \pm 0.03$ & $0.450 \pm 0.03$ & 0.66 & $>0.05$ & \multirow{2}{*}{0.40 and $<$} \\
\hline & & 0 & $0.450 \pm 0.03$ & $0.340 \pm 0.02$ & 5.50 & $<0.001$ & \\
\hline & & $\mathbf{t}$ & 0.50 & 2.75 & - & - & - \\
\hline & & $\mathbf{P}$ & $>0.05$ & $<0.05$ & - & - & - \\
\hline \multirow{4}{*}{3.} & \multirow{4}{*}{$\begin{array}{l}\text { Sensorimotor reaction } \\
\text { to light }(\mathrm{sec})\end{array}$} & $\mathbf{K}$ & $0.420 \pm 0.03$ & $0.401 \pm 0.03$ & 0.63 & $>0.05$ & \multirow{2}{*}{0.37 and $<$} \\
\hline & & 0 & $0.400 \pm 0.03$ & $0.320 \pm 0.02$ & 5.20 & $<0.001$ & \\
\hline & & $\mathbf{t}$ & 0.25 & 2.37 & - & - & - \\
\hline & & $\mathbf{P}$ & $>0.05$ & $<0.05$ & - & - & - \\
\hline \multirow[t]{2}{*}{4.} & \multirow{2}{*}{\multicolumn{2}{|c|}{$\begin{array}{l}\text { Complex visual-motor reaction } \\
\text { «MOR»: sec }\end{array}$}} & & & \multirow{2}{*}{\multicolumn{3}{|c|}{$\begin{array}{l}\text { Expected }(\mathrm{Age}) \\
\text { results }\end{array}$}} \\
\hline & & & Initial & Final & & & \\
\hline \multirow[t]{2}{*}{4.1.} & \multirow{2}{*}{$\begin{array}{l}\text { - acceleration reaction } \\
\text { «-» }(\%)\end{array}$} & $\mathbf{K}$ & $-0.88 \sec 34 \%$ & $-0.76 \sec 28 \%$ & \multirow{2}{*}{\multicolumn{3}{|c|}{$-0.42 \sec 10 \%$}} \\
\hline & & 0 & $-0.81 \sec 45 \%$ & $-0.40 \sec 14 \%$ & & & \\
\hline \multirow[t]{2}{*}{4.2 . } & \multirow{2}{*}{$\begin{array}{l}\text { - delayed reaction «+» } \\
(\%)\end{array}$} & $\mathbf{K}$ & $+1.56 \sec 55 \%$ & $+0.70 \sec 48 \%$ & \multirow{2}{*}{\multicolumn{3}{|c|}{$+0.39 \sec 15 \%$}} \\
\hline & & 0 & $+1.20 \sec 50 \%$ & $+0.37 \sec 16 \%$ & & & \\
\hline \multirow[t]{2}{*}{4.3} & \multirow{2}{*}{ - timely reaction \% } & $\mathbf{K}$ & $2 \%$ & $8 \%$ & \multirow{2}{*}{\multicolumn{3}{|c|}{$75 \%$}} \\
\hline & & 0 & $13 \%$ & $70 \%$ & & & \\
\hline
\end{tabular}

Notes: $\mathrm{n}_{\mathrm{K}}=15 ; \mathrm{n}_{\mathrm{o}}=15$. $\mathbf{K}-$ control group; $\mathbf{O}$ - experimental group.

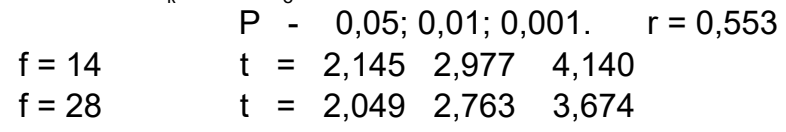

In Table 1 (upper part of the first colon) are presented the "expected results" nr. 1; nr. 2 and nr. 3, which reflect the necessary age results. In this respect, as is presented by the final results of the control group of sambo athletes, there is a mismatch to the expected level of representation (tapping test: the real quantity indicator is below the expected one; the real results of light and sound reaction tests above the expected level (i.e. they must be equal or below the expected norm)). At the same time, the same results of the experimental group of sambo athletes are the following: tapping-test exceed the level expected for their age; for reaction to light and sound also exceed the expected level.

The bottom part of Table 1 shows the initial and final results of the studied groups for the test "Complex visual and motor reaction to a moving object" (RMO) and their comparative dynamics. It is worth mentioning that the observation object for the examinees was the moving time of the millisecond timer, with the fixation of its time by the examinees at the appearance of reading on screen - 10 seconds. Moreover, there were registered "accelerated" (up to 10 seconds, with "-"), "timely" and "delayed" (after 10 seconds, with "+") reactions.

The analysis of the presented results is indicative of the fact that at the initial experiment stage for the test "Complex visual and motor reaction to a moving "object" the indices for every type of reaction to the "object" movement for both studied groups have basically the same level. At the same time, in every studied group of sambo athlete and for every type of reaction, the final results are different in comparison to the initial ones. So, the "accelerated" reaction in the control group to the end of the experiment improved only for 0.12 seconds, but their "delayed reaction" had a more visible improvement -0.86 seconds. It is also necessary to notice that for the very important "timely" reaction the sambo athletes in the control group at the end of experiment had an improvement of only $6 \%$.

At the same time the final experiment results of the experimental group shows that the reaction time for RMO had a more significant improvement compared to the control group: for "accelerated" reaction - 
0.40 seconds; "delayed" reaction -0.37 seconds, and this result exceeds the expected age result for this test. For the important "timely" reaction the sambo athletes of the experimental group achieved a result of $70 \%$, which is $\mathbf{5 7} \%$ bigger compared to the initial stage of the experiment. Moreover, this increase of the timely reaction to the moving object of the sambo athletes of the experimental group to the end of the experiment (up to $70 \%$ ) is explained by the same preliminary readiness (selection results) and the same active experimental and training influence on them throughout the study and training year.

We also studied the decrease dynamics of touches in the tapping test, which is characteristic of "fine" motor skills in every 10 seconds period, which also, to a certain degree characterizes the increase, for 4 periods, of tiredness of the brain motor center and conducting neuromuscular body systems of the studied sambo athletes. These data are presented in Table 2 (At the initial and final experiment stage).

Table 2 presents the results of the tapping test of the beginner sambo athletes in the pedagogical experiment.

As reflected by Table 2, the results of the tapping test of the studied sambo athletes decrease inconclusively in terms of quantity for every time period.

Table 2 - Presentation of the tapping test results for beginner sambo athletes in the pedagogical experiment

\begin{tabular}{|c|c|c|c|c|c|}
\hline \multirow[t]{2}{*}{$\begin{array}{l}\text { 음 } \\
\text { 이 }\end{array}$} & \multicolumn{4}{|c|}{$\begin{array}{l}\text { Time period and the amount of } \\
\text { made touches (movements) } \bar{x}\end{array}$} & \multirow{2}{*}{$\begin{array}{c}\begin{array}{c}\text { Total } \\
\text { amount of } \\
\text { movements }\end{array} \\
-\end{array}$} \\
\hline & $\begin{array}{c}\text { 1-st } \\
\text { period }\end{array}$ & $\begin{array}{l}\text { 2-nd } \\
\text { period }\end{array}$ & $\begin{array}{l}\text { 3-rd } \\
\text { period }\end{array}$ & $\begin{array}{l}\text { 4-th } \\
\text { period }\end{array}$ & \\
\hline \multicolumn{6}{|c|}{ Initial stage of the experiment } \\
\hline K & 70 & 51 & 38 & 29 & 188 \\
\hline 0 & 74 & 54 & 40 & 32 & 200 \\
\hline \multicolumn{6}{|c|}{ Final stage of the experiment } \\
\hline K & 71 & 55 & 42 & 31 & 199 \\
\hline 0 & 75 & 64 & 55 & 40 & 234 \\
\hline
\end{tabular}

Thus, this decrease is more pronounced in the control group compared to the experimental group of sambo athletes. This fact evidences that the fatigability of the psychomotor processes of the sambo athletes in the experimental group is considerably less significant compared to the control group.

This fact is confirmed by Fig. 1, where the graphic indices trend of the tapping test is presented in the experimental groups from the first to fourth period. They indicate the fact that local tiredness of the conducting

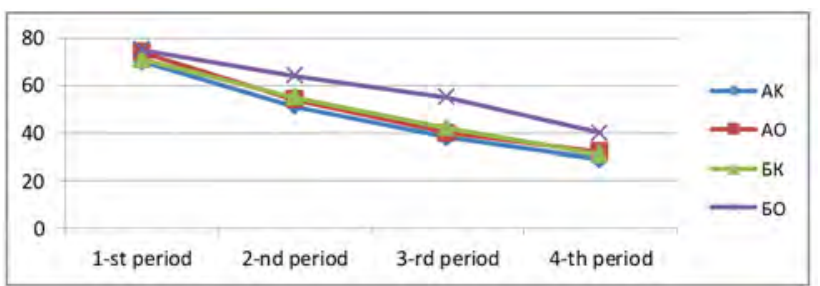

Fig. 1. Indices dynamics of the tapping- test from the first to fourth time periods obtained from the beginner sambo athletes in the experimental groups at the initial and final stage of the pedagogical research experiment

Specification: AO - indices of the experimental group at the initial stage of the experiment; $\mathbf{A K}$ - indices of the control group at the initial stage of the experiment; $\mathbf{5 O}$ indices of the experimental group at the final stage of the experiment; БK - indices of the experimental group at the final stage of the experiment

neuromuscular body systems of the studied sambo athletes is caused by the inhibition of their brain motor center and it is increasing in both groups, but with a more prominent tendency to regression to the fourth period in the control group. At the same time, in the experimental group at the end of the research this process was far less prominent.

Conclusion. Thus, the study of the psychomotor abilities of the beginner sambo athletes in the studied groups had shown that in the experimental group, which included the experimental program of sport diagnostics for 8-9 years old boys for initial sport selection for sambo wrestling, including a complex of scientifically based criteria and conditions, allowed for a higher degree of possibility in selecting the best candidates that would be able to obtain high sport results and in( удалить) were potentially better than the control group. The obtained results are veridically expressed and correspond to the adequate age norm, which is opposite to the results of the control group. This fact also confirms our supposition that the specialized initial sport selection of 8-9 years old pupils based on scientific factors, contributes to a more progressive sport improvement even in beginner sambo athletes with a stable perspective of maintaining the capable contingent of athletes and successful and timely addressing the problem of the execution of necessary classification norm in sambo wrestling.

Perspectives of further research. UnfortunateIy, the scientific research dedicated to the study of the psychomotor abilities of 8-9 years old children in the process of selection for systematic sambo training is largely absent. The next objective of our research will be oriented towards the identification of motor and coordination development of beginner sambo athletes.

\section{References}

1. Guba VP. Current problems of modern theory and methodology of determining early sport talent. Theory and practice of physical training. 2000; 9: 28-31. 
2. Seluianov VN, Shestacov MP. Identfication of aptitudes and talent scouting in sport. Sport Academy. M: Press; 2000. $112 \mathrm{p}$.

3. Sushko R, Vysochina N, Vorobiova A, Doroshenko E, Pastuhova V, Vysochin F. Psychological Selection in Game Sports on the Basketball Example. Journal of Physical Education and Sport. 2019; 19(3): 1708-1714. doi: 10.7752/jpes.2019.03250

4. Moskovchenko O, Ivanitsky V, Shumakov A, Tolstopyatov I, Kattsina T, Redi Elena, et al. Morphofunctional markers of kinetic aptitude in a sport selection system. Journal of Physical Education And Sport $®$ (Jpes). 2018; 2 (98): 670-676.

5. Moscovcenco ON, Shumacov AV. Training of wrestlers of Greco-Roman style on the basis of sport selection. Sport complex journal. 2019; 1(13): 43-47.

6. Custov FI, Ponomarev VV, Serova OR. Additional preprofessional sambo program for initial training. Ekaterinburg; 2016. 46 p.

7. Abdullaev AC. Pedagogical basis of sport selection of wrestlers. Pedagogy, Psychology and methodological and biological problems of physical education and sport. 2011; 08: 3-5.

8. Nikitushkin VG. Modern training of young athletes. Study guide. M; 2009. $112 \mathrm{p}$.

9. Obuhova LF. Developmental Psychology. Study Guide. Pedagogical Society; 1999. 442 p.

10. Shegelman IR, Godinov AN. The methodology of the approach to improving the system of endto-end training and selection in the Russian national sport - sambo (self-defence without weapons). Journal of Human Sport and Exercise. 2020; 5 (3): S973-S986. doi: 10.14198/jhse.2020.15.Proc3.49

11. Markov KK. Improving Personal Skills Coach in Successful Sports Activities. Current problems of science and education. 2017; 5.

12. Iglin AV. Sport and economics. Journal of MUFL. 2018; 3: 77-87.

13. Galkin VV. Sport Economics and Business. Study Guide. Knorus; 2006. 320 p.

14. Polevaia-Secareanu A. Intensification of the study and training process by means of rhythmic education and music at the stage of initial sport specialization in judo. Thesis doctor of education; 2012. $180 \mathrm{p}$.

15. Romanov VV. Methodology of sport selection of sambo wrestlers at the training stage. Abstr. PhDr. (Ped.). M; 2006. $164 \mathrm{p}$.

16. Scorina AA. Methodological aspects of judoka selection at the stage of initial sport specialization. Modern problems of physical education and sport training methodology. Grodno: YKST; 2011. p . 254-259.

17. Morozov AA. Psychomotor tests in the selection system of wrestlers with different qualification. Abstr. PhDr. (Ped.). M; 2001. $125 \mathrm{p}$.

18. Manolachi V. The perfection of sports selections at the children's initial training stage in judo. New educational evolutions for sports, management, health therapy and free time in European context: International scientific conference. Braşov; 2010. p. 60.

19. Scorina AA. Realisation of sport selection in judo from the trainer perspective. Health for everyone: materials of the IV International Scientific and Practical Conference "Polessky State University", Pinsk, 2012. 2012; p. 272-276.

20. Manolachi $\mathrm{V}$. The determination of the heriditary features of children's physical development of the initial sports selection in judo. International scientific conference "New educational evolutions for sports, management, health therapy and free time in European context», 2010. 2010; p. 56.

\section{Удк 796.814:796.012.2-048.58-057.874}

\section{ОСОБЛИВОСТІ ПОЧАТКОВОГО СПОРТИВНОГО ВІДБОРУ \\ БОРЦІВ-САМБІСТІВ МОЛОДШОГО ШКІЛЬНОГО ВІКУ \\ НА ОСНОВІ ВИВЧЕННЯ ПСИХОМОТОРНИХ ЗДІБНОСТЕЙ}

Баралюк І. М., Манолакі В. В., Польова-Секеряну А. Г., Которча А. В.

Резюме. Мета даного дослідження - виявити особливості психомоторних властивостей у дітей самбістів 8-9 років в процесі початкового спортивного відбору. У дослідженні представлено алгоритм провідних чинників поетапного проходження відбору 165 школярів 8-9 років для боротьби самбо. Першим етапом відбору був поглиблений медичний контроль, який визначив, що понад $50 \%$ (68) дітей 3 усього контингенту мають порушення морфології, функціональності різних систем їх організму. На третьому етапі відбору визначення інтелектуальних можливостей показало, що тільки 73,53\% дітей з 68 осіб (50 дітей) мають середній рівень стійкості уваги. За оцінкою психомоторних здібностей школярів виявлено зниження контингенту на $20 \% 350$ осіб. На особливому етапі відбору 17,5\% школярів 8-9 років в 70\% випадків (тобто по більшості тестів) не впоралися з виконанням вимог по руховим здібностям і координаційним можливостям. Основний експеримент був спроектований і реалізований на основі річного педагогічного експерименту, для якого були організовані дві досліджувані експериментальні групи самбістів першого року спортивної підготовки: контрольна група, набраних без спеціального відбору (тобто 
з далекого резерву дітей) в кількості 15 чоловік, і група дослідження в кількості 15 спеціально відібраних хлопчиків 8-9 років. Тільки в дослідну групу була включена експериментальна методика спортивної діагностики, яка містить комплекс науково обґрунтованих критеріїв і умов. Під час експерименту виявлено показники «своєчасної» реакції самбістів контрольної групи, які стали краще до кінця експерименту тільки на 6\% в порівнянні з групою дослідження (на 57\% більше, ніж був показник на початку експерименту). Представлена динаміка теппінг-тесту досліджуваних самбістів в експериментальних групах, від першого до четвертого періодів, де наочно виражена локальна стомлюваність нервово-м'язової системи організму, обумовлена пригніченням рухових центрів головного мозку, яка наростає в обох групах, але особливо з явно вираженою тенденцією погіршення до 4-му періоду в контрольній групі (з першого до четвертого періоду - в межах 62,80\%) в порівнянні з групою дослідження, де швидкість елементарних рухів дітей в теппінг-тесті знижується в кожному часовому періоді неоднозначно. До кінця 2-го періоду результати групи дослідження знизилися на 11,25\%, до кінця 3-го періоду - на 36,62\%, до кінця 4-го періоду - на 15,55\% від даних попередніх періодів, що в підсумку становить зниження від першого до четвертого періодів - до 63,42\% Така достовірно значуща ситуація психомоторного розвитку в дослідній групі самбістів, на думку авторів, стала можливою через їх попередню готовність (результат відбору), та активним експериментально-тренувальним впливом на них.

ключові слова: селекція, самбо, початковий етап, сенсомоторіка.

УДК 796.814:796.012.2-048.58-057.874

ОСОБЕННОСТИ НАЧАЛЬНОГО СПОРТИВНОГО ОТБОРА

БОРЦОВ-САМБИСТОВ МЛАДШЕГО ШКОЛЬНОГО ВОЗРАСТА

НА ОСНОВЕ ИЗУЧЕНИЯ ПСИХОМОТОРНЫХ СПОСОБНОСТЕЙ

Баралюк И. М., Манолаки В. В., Полевая-Секэряну А. Г., Которча А. В.

Резюме. Цель данного исследования - выявить особенности психомоторных свойств у детей самбистов 8-9 лет в процессе начального спортивного отбора. В исследовании представлен алгоритм ведущих фракторов поэтапного прохождения отбора 165 школьников 8-9 лет для борьбы самбо. Первым этапом отбора был углубленный медицинский контроль, в результате которого установлено, что более $50 \%$ детей (68) из всего контингента проверяемых имеют нарушения морфологии, функциональности различных систем организма. На третьем этапе отбора определение интеллектуальных возможностей показало, что только 73,53\% детей из 68 человек (50 человек) обладают средним уровнем устойчивости внимания. По оценке психомоторных способностей школьников выявлено снижение контингента на $20 \%$ из 50 человек. На особом этапе отбора 17,5\% школьников 8-9 лет, в 70\% случаев (то есть по большинству тестов) не справились с выполнением требований по двигательным способностям и координационным возможностям. Основной эксперимент был спроектирован и реализован на основе годичного педагогического эксперимента, для которого были организованы две изучаемые экспериментальные группы самбистов первого года спортивной подготовки: контрольная группа, набранная без специального отбора (то есть из далекого резерва детей), в количестве 15 человек, и опытная группа в количестве 15 специально отобранных мальчиков 8-9 лет. В опытной группе проводилась экспериментальная методика спортивной диагностики, содержащая комплекс научно обоснованных критериев и условий.

Во время эксперимента выявлены показатели своевременной реакции среди самбистов контрольной группы, которые к концу эксперимента стали лучше только на 6\% по сравнению с опытной (на $57 \%$ больше, чем был показатель в начале эксперимента). Представлена динамика теппинг-теста изучаемых самбистов в экспериментальных группах, от первого до четвертого периодов, где наглядно показана локальная утомляемость нервно-мышечной системы организма, обусловленная угнетением двигательных центров головного мозга, которая нарастает в обеих группах, но особенно с явно выраженной тенденцией ухудшения к 4-му периоду в контрольной группе (с первого до четвертого периода в пределах 62,80\%) по сравнению с опытной группой, где быстрота элементарных движений детей в теппинг-тесте снижается в каждом временном периоде неоднозначно. Так к концу 2-го периода результаты опытной группы снизились на 11,25\%, к концу 3-го периода - на 36,62\%, к концу 4-го периода - на 15,55\% от данных предыдущих периодов, что в итоге составляет снижение от первого до четвёртого периодов - до 63,42\%. Такая достоверно значимая ситуация психомоторного развития в опытной группе самбистов, по мнению авторов, стала возможной по причине их предварительной готовности (результат отбора), и активным экспериментально-тренировочным воздействием на них.

Ключевые слова: селекция, самбо, начальный этап, сенсомоторика.

The authors of this study confirm that the research and publication of the results were not associated with any conflicts regarding commercial or financial relations, relations with organizations and/or individuals who may have been related to the study, and interrelations of coauthors of the article. 